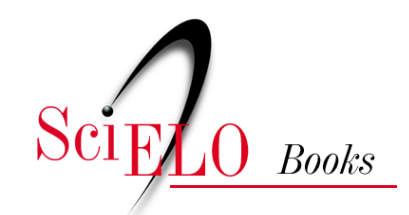

\title{
A importância da mobilidade populacional para a acumulação capitalista no setor petróleo e gás da Bacia de Campos (RJ)
}

\author{
Denise Cunha Tavares Terra \\ Joseane de Souza
}

\section{SciELO Books / SciELO Livros / SciELO Libros}

TERRA, D.C.T., and SOUZA, J. A importância da mobilidade populacional para a acumulação capitalista no setor petróleo e gás da Bacia de Campos (RJ). In: MARAFON, G.J., and RIBEIRO, M.A. orgs. Revisitando o território fluminense, VI [online]. Rio de Janeiro: EDUERJ, 2017, pp. 327351. ISBN: 978-85-7511-457-5. https://doi.org/10.7476/9788575114575.0017.

All the contents of this work, except where otherwise noted, is licensed under a Creative Commons Attribution 4.0 International license.

Todo o conteúdo deste trabalho, exceto quando houver ressalva, é publicado sob a licença Creative Commons Atribição $\underline{4.0}$.

Todo el contenido de esta obra, excepto donde se indique lo contrario, está bajo licencia de la licencia $\underline{\text { Creative Commons }}$ $\underline{\text { Reconocimento } 4.0 .}$. 


\section{A importância da mobilidade populacional para a acumulação capitalista no setor petróleo e gás da Bacia de Campos (RJ)}

Denise Cunha Tavares Terra

Joseane de Souza

\section{Introdução}

$\mathrm{N}$ os últimos dois séculos, o petróleo foi fator de transformação significativa da economia, do espaço e da sociedade nos países produtores do mundo periférico e semiperiférico. A atividade de exploração e produção de petróleo e gás proporcionou divisas, energia e matérias-primas, bem como o início do processo de industrialização em muitos desses países. A atual matriz energética mundial ainda é dependente do petróleo. Segundo Egler e Mattos (2012), cerca de 65\% da oferta global de energia primária provém do petróleo e do gás natural, o que permite a compreensão do alcance de sua influência nos rumos da geopolítica global.

No Brasil, o processo acelerado de expansão da indústria petrolífera e os investimentos realizados na última década produziram alterações significativas na espacialização da riqueza nacional, com rebatimentos na conformação da rede urbana brasileira.

No Norte Fluminense, a partir de meados dos anos 1970, com a implantação da Petrobras no município de Macaé, porém mais intensamente a partir do final dos anos 1990, com a quebra do monopólio da exploração e produção de petróleo no país e a consequente vinda de empresas petrolíferas e parapetrolíferas, a economia tem-se alicerçado cada vez mais em torno da economia do petróleo, em especial das rendas petrolíferas (royalties e participações especiais).

O município de Macaé é onde se localiza a base de operações das empresas petrolíferas e parapetrolíferas, bem como de um grande número de empresas fornecedoras de insumos para elas. Nesse município, ampliou-se consideravelmente, ao longo das últimas décadas, a oferta de empregos formais com salários acima da média regional. 
Estudos recentes desenvolvidos por Souza, Terra e Campos (2012 e 2015) e Souza e Terra (2015) apresentam, a partir de análises relacionadas à mobilidade populacional (migrações internas e movimentos pendulares), fortes indícios de que as antigas mazelas de nosso histórico de urbanização estão se reproduzindo nos municípios produtores de petróleo da Bacia de Campos. Macaé, onde as políticas públicas são mais voltadas aos interesses das empresas petrolíferas e parapetrolíferas, obedecendo à racionalidade capitalista, é um claro exemplo de cidade que apresenta sérios problemas de saneamento, moradia, violência, congestionamento de tráfego e poluição, entre outros. Além disso, como nos lembra Piquet (2012), as tensões existentes são muitas vezes provocadas por um crescimento dependente de decisões exógenas, que transcendem o local e geram,

[...] de um lado, a riqueza do petróleo, as perspectivas de novos postos de trabalho, o aparecimento de novas empresas; de outro, a população em crescimento exponencial, os problemas sociais, a violência, o déficit dos serviços urbanos e sociais. Não é trivial a avaliação desses impactos, uma vez que sua influência ultrapassa em muito a esfera local/regional e, conforme comentado anteriormente, dada a importância da indústria do petróleo para qualquer país - seja como fonte energética, seja como elemento catalisador de divisas, seja como setor estratégico ou ainda como base de apoio à industrialização -, sua influência dificilmente irá limitar-se a espaços subnacionais (p. 160).

Nesse sentido, a atividade de exploração e produção offshore de petróleo e gás na Bacia de Campos vem, ao longo de quase quarenta anos, e de forma mais significativa nos últimos 18 anos, produzindo uma nova dinâmica territorial, demográfica e socioeconômica no interior do estado do Rio de Janeiro, em especial nas aglomerações urbanas de Campos dos Goytacazes, Macaé e Cabo Frio, identificadas na recente publicação do IBGE Arranjos populacionais e concentraçôes urbanas no Brasil (2015) como casos especiais de formas urbanas a serem acompanhados. Esses novos espaços regionais são incorporados à dinâmica econômica estadual, que se torna dependente do setor de petróleo e gás.

O objetivo deste artigo é discutir a importância da mobilidade populacional para o processo de acumulação capitalista, na Bacia de Campos, à luz das contribuições teóricas de David Havey (2005). Para esta análise, considera-se, principalmente, o Censo Demográfico de 2010, única fonte para estudo das migrações e pendularidade em áreas não metropolitanas.

Para que a análise se torne mais clara, apresentam-se, nas duas primeiras seções, uma breve caracterização da indústria petrolífera brasileira e alguns elementos para a compreensão da geografia da acumulação capitalista. Na terceira seção, analisam-se os fluxos migratórios e pendulares, as características socioeconômicas dos trabalhadores naturais e também daqueles atraídos pelas atividades econômicas desenvolvidas nos municípios da Bacia de Campos, assim como o nível de dependência desses municípios em relação à mão de obra exógena. Nas consideraçôes finais, articula-se a importância da mobilidade populacional para o processo de acumulação capitalista. 


\section{Breve caracterização da indústria petrolífera brasileira}

O petróleo é um insumo de grande importância para a manutenção da atividade econômica mundial. Como as reservas são distribuídas de forma desigual entre os países e entre regiōes de um mesmo país, o custo de produção varia e a competição é acirrada, gerando fortes disputas geopolíticas.

No Brasil, a busca pelo petróleo foi movida não só por fatores econômicos, mas também por uma afirmação de nacionalidade, tanto que, em 1938, a discussão sobre o tema petróleo já se fazia presente e relevante, tendo sido criado, nesse mesmo ano, o Conselho Nacional de Petróleo, que tratou a questão do abastecimento como de utilidade nacional, passando a controlar a produção, o refino e a distribuição.

Em 1939, teve início a produção de petróleo em um dos poços do campo de Lobato, na Bahia. $\mathrm{Na}$ ocasião, o debate se tornou ainda mais acirrado, pois havia uma polêmica quanto ao fato de o governo brasileiro se tornar responsável pela atividade petrolífera no país, além de dúvidas sobre a existência de reservas que justificassem o volume necessário de investimentos. Naquela época, a exploração era realizada no mundo, em grande parte, por empresas norte-americanas, e o debate sobre a necessidade ou não de capital estrangeiro durou até 1953, quando foi criada a Petrobras, no governo de Getulio Vargas, garantindo-se à União o monopólio da pesquisa, da lavra, do refino e do transporte (Farias, 2003, p. 17).

Caetano Filho (2003, p. 45) aponta que houve períodos em que a exploração de petróleo não era economicamente viável, devido ao preço internacional do barril. Mesmo assim, visóes equilibradas e não apequenadas fizeram com que os investimentos continuassem a ser feitos, com vistas a conquistar domínio tecnológico nesse setor tão estratégico para o país. A decisão se mostrou acertada quando, em 1973, com a primeira crise do petróleo, o preço do barril mais que dobrou no mercado internacional.

À época, despontava a produção da Bacia de Campos, atualmente reconhecida como a maior bacia petrolífera do país, transformando os municípios produtores do estado do Rio de Janeiro nos maiores recebedores de royalties e participações especiais, o que gerou crescente polarização e concentração de recursos nos municípios litorâneos do Norte Fluminense e das Baixadas Litorâneas, em especial a partir da Lei do Petróleo, de 1997. Foi essa legislação que ampliou a alíquota dos royalties de $5 \%$ para até $10 \%$, flexibilizando o monopólio de exploração e produção de petróleo, e permitindo a entrada de outras petroleiras, através da adoção do modelo de concessão em exploração e produção.

A indústria petrolífera exige uma variedade de tecnologias nas fases de perfuração e sondagem, atividades de grande complexidade tecnológica para a exploração e a produção, bem como conhecimentos em áreas multidisciplinares. Apresenta dois importantes segmentos, ambos apresentando atividades intensivas em capital, denominados upstream (fases de exploração, desenvolvimento e produção) e downstream (transporte, refino e distribuição).

As empresas que atuam nesses segmentos apresentam portes diversificados, sendo que as petroleiras (oil companies) desempenham papel central, tornando-se responsáveis pela contratação de serviços como os de sísmica, perfuração e produção; também contratam outras empresas altamente 
especializadas que, devido ao nível de sofisticação tecnológica necessário nas operações, pertencem, em sua maioria, a importantes oligopólios internacionais (Piquet e Terra, 2011).

Percebe-se a existência de uma nítida divisão de mercado nesse setor. As pequenas e médias empresas, de âmbito local/regional, inserem-se de forma subalterna, ofertando uma variedade de produtos e serviços de baixo conteúdo tecnológico, enquanto as empresas transnacionais executam tarefas mais rentáveis e sofisticadas. Essa divisão também existe no mercado de trabalho, como se verá adiante.

A rede logística perpassa a escala local, sendo de fundamental importância para a atividade, pois demanda melhorias e adequação no sistema de transporte, seja para o escoamento da produção, seja para as demandas de equipamentos e peças voltados à própria atividade de exploração e produção, favorecendo, dessa forma, ainda que indiretamente, o deslocamento da mão de obra, essencial ao processo de acumulação capitalista nesse espaço.

Além das melhorias anteriores impostas pela atividade, percebe-se, nos municípios que integram a Bacia de Campos, uma ampliação do sistema de telecomunicações, provedores de internet e linhas telefônicas, o que se torna típico dessa fase de compressão do tempo-espaço. Apoiado nas redes de telecomunicações, nos avanços na rede de transporte e na expansão do mercado de trabalho, trabalhadores de alta e baixa qualificação do próprio estado e dos demais estados brasileiros, e até mesmo trabalhadores internacionais altamente qualificados, são atraídos para a região.

Em 2007, o Brasil entrou em uma nova etapa no setor petrolífero. A Petrobras confirmou a existência de uma grande jazida de petróleo na Bacia de Santos, na camada pré-sal, com potencial para ampliar em até $40 \%$ a extração de petróleo no país. Nesse contexto, diante da expectativa de se ampliar a produção de petróleo e gás, foi proposto um novo marco regulatório para o setor, destacando-se a alteração do modelo de concessão para o de partilha de produção no caso dos contratos de exploração e produção nas áreas ainda não licitadas do polígono do pré-sal, acreditando-se que o novo modelo estaria mais afeito à preservação do interesse nacional, mediante a maior participação nos resultados e o maior controle da riqueza gerada. Assim, a partir de 2010, o Brasil passou a contar com um modelo misto de exploração e produção de petróleo e gás (Terra et al., 2014).

Segundo dados da ANP (2015), em 2014, o Brasil alcançou reservas provadas de petróleo de 16,2 bilhōes de barris, com 13,2 bilhōes dos barris localizados no estado do Rio de Janeiro, ou seja, $81,5 \%$ das reservas de petróleo provadas do Brasil encontram-se nesse estado da federação. Já a produção de petróleo brasileira atingiu 822,9 milhões de barris nesse mesmo ano, sendo o estado do Rio de Janeiro responsável por 563,2 milhões, ou seja, 68,4\% da produção de petróleo nacional. Esses dados revelam a importância presente e futura desse setor para a economia do estado do Rio de Janeiro.

No entanto, levando-se em conta a queda do preço do barril de petróleo no mercado internacional e os problemas atualmente enfrentados pela Petrobras, com o desdobramento da Operação Lava-Jato, está havendo mudanças significativas tanto na capacidade de investimentos diretos e indiretos como no mercado de trabalho desse setor. 


\section{Contribuições da geografia da acumulação capitalista}

A abordagem elaborada por Harvey (2001 [1975]) pode ser útil para nosso entendimento acerca das contradiçôes impostas pelo peso da atividade petrolífera na economia do estado do Rio de Janeiro. Isso porque essa teoria nos ajudaa a refletir e analisar as contradiçôes inerentes às atividades de exploração e produção de petróleo no território fluminense, pois o petróleo, como afirma Costa (2012),

[...] é o maior e mais disseminado negócio, a maior entre as maiores indústrias que se desenvolveram nas últimas décadas do século XIX. Nenhum outro negócio determina de maneira tão completa e radical o significado do risco e da recompensa, e o profundo impacto da oportunidade e do destino (p. 55).

A geografia da acumulação nos traz elementos para compreender as contradições existentes no próprio capitalismo, com seus aspectos de destruição e preservação. Essas contradiçôes é que promovem a dinâmica da circulação e a permanente necessidade de reduzir o tempo de circulação do capital, o que justifica os constantes investimentos em comunicações e transportes, com foco principal no comércio exterior, promovendo a evolução da formação social capitalista para diferentes fronteiras.

Harvey estabelece algumas categorias de análise e articula a teoria da acumulação capitalista, elaborada por Marx, com a dimensão espacial. Segundo Harvey, a necessidade de acumulação implica, consequentemente, a superação das barreiras espaciais. Dessa forma, estimula formas mais baratas e rápidas de comunicação e transporte, auxiliando a inserção de novos espaços para acumulação de capital. De modo recíproco, a acumulação de capital busca ser "geograficamente expansível", resultando em crescente redução do custo de comunicação e transporte. No entanto, como nos adverte, é necessário promover melhora na velocidade de circulação do capital para compensar o acesso a mercados mais distantes e o aumento de seu tempo de giro. Para Harvey (2005, p. 53), “a expansão geográfica e a concentração geográfica são ambas consideradas produtos do mesmo esforço de criar novas oportunidades para a acumulação de capital”. A própria estrutura espacial que surge com o processo capitalista de produção não está isenta de contradições, agindo também como barreira para a acumulação adicional. Isso se deve à crescente dependência do capitalismo ao capital fixo.

Essa paisagem geográfica, que contempla o capital fixo e imobilizado, pode ser vista como valor de uso e incentivadora da acumulação de capital, e também como "inibidora do progresso adicional de acumulação". Isso se deve à própria contradição e à tensão inerentes ao modo capitalista de produção, que "precisa superar o delicado equilíbrio entre preservar o valor dos investimentos passados de capital na construção do ambiente e destruir esses investimentos para abrir espaço novo para a acumulação" (idem, p. 54).

Outro elemento analisado é o crescimento do comércio exterior impulsionado pelo modo capitalista de produção. Para Marx, segundo Harvey (2005), o comércio exterior é, ao mesmo tempo, uma condição prévia para a acumulação capitalista e consequência da expansão do mercado. Além disso, sugere que a tendência histórica do capitalismo "é destruir e absorver modos de produção não capitalistas", concomitantemente à sua utilização para gerar novos espaços de acumulação do capital. A forma como as relações sociais capitalistas se inserem nas economias não capitalistas se dá pela ge- 
ração e a perpetuação do atraso e do subdesenvolvimento, refutando-se, portanto, a ideia de que, no capitalismo, é possível atingir um desenvolvimento equilibrado das diferentes esferas de produção, resultando em melhora de vida para a maior parte da população.

Ao contrário, o desenvolvimento capitalista desigual, ao induzir a expansão geográfica em escala global, gera, como subproduto, o desenvolvimento desigual da luta de classes. Como aponta Harvey (idem, p. 71), "o caminho da acumulação capitalista seguirá por onde a resistência for mais fraca" e mostra como Marx é enfático ao tratar o capital como um processo de circulação entre produção e realização.

Esse processo deve se expandir, acumular, reformar constantemente o processo de trabalho e os relacionamentos sociais na produção, assim como mudar constantemente as dimensões e as formas de circulação. Marx ajuda a entender esses processos teoricamente. No entanto, no fim, temos que fazer essa teoria se relacionar com situaçôes existentes na estrutura das relações sociais capitalistas desse momento da história. [...] Elaborar e reelaborar a teoria da acumulação de Marx como totalidade, numa escala geográfica expansível, requer essa inserção (Harvey, 2005, p.7).

\section{A mobilidade populacional na Bacia de Campos}

Apesar dos vários elementos apontados por Harvey (2005) - transformação das estruturas espaciais e do mercado de trabalho, variações dos investimentos fixos e imobilizados, transformação da paisagem geográfica, criada para permitir a acumulação por meio da produção e da circulação -, optou-se, neste artigo, por compreender o papel da mobilidade populacional - migrações internas e pendularidade -, grande parte direcionada ao atendimento da demanda do mercado de trabalho, por entendê-la de fundamental importância para o processo de acumulação capitalista no setor de petróleo e gás na Bacia de Campos.

O estado do Rio de Janeiro, que, em 1991, tinha uma população de 12.807.195 habitantes, atingiu, em 2010, uma população de 15.989.929 habitantes, tendo experimentado uma taxa de crescimento médio anual da ordem de 1,33\% entre 1991-2000 e de 1,06\% entre 2000-2010 (Tabela 1). O baixo ritmo de crescimento da população estadual se explica, por um lado, pela redução da fecundidade - que, em 2005, segundo o IBGE (2009), encontrava-se significativamente abaixo do nível de reposição e em torno de 1,8 filho por mulher no final do período reprodutivo - e, por outro lado, pela mudança no padrão migratório brasileiro. 
Tabela 1. Rio de Janeiro: população, taxa de crescimento médio anual e participação relativa no incremento absoluto, por mesorregião (1991-2010)

\begin{tabular}{|c|c|c|c|c|c|c|c|c|c|c|}
\hline \multirow{3}{*}{ Mesorregião } & \multicolumn{6}{|c|}{ População } & \multicolumn{2}{|c|}{$\begin{array}{c}\text { Taxa de } \\
\text { Crescimento }\end{array}$} & \multicolumn{2}{|c|}{$\begin{array}{c}\text { Participação } \\
\text { relativa no } \\
\text { incremento absoluto }\end{array}$} \\
\hline & \multicolumn{2}{|l|}{1991} & \multicolumn{2}{|l|}{2000} & \multicolumn{2}{|l|}{2010} & \multirow{2}{*}{$\begin{array}{c}1991 \text { - } \\
2000\end{array}$} & \multirow{2}{*}{$\begin{array}{c}2000- \\
2010\end{array}$} & \multirow{2}{*}{$\begin{array}{c}1991- \\
2000\end{array}$} & \multirow{2}{*}{$\begin{array}{c}2000- \\
2010\end{array}$} \\
\hline & Absoluto & $\%$ & 2000 & $\%$ & 2010 & $\%$ & & & & \\
\hline$\overline{\text { Noroeste }}$ & 273.062 & 2,1 & 297.837 & 2,1 & 317.493 & 2,0 & $\overline{1,0}$ & $\overline{0,6}$ & 1,6 & $\overline{1,2}$ \\
\hline Norte & 611.576 & 4,8 & 699.292 & 4,9 & 849.515 & 5,3 & 1,5 & 2,0 & 5,5 & 9,4 \\
\hline Centro & 425.375 & 3,3 & 452.646 & 3,1 & 481.357 & 3,0 & 0,7 & 0,6 & 1,7 & 1,8 \\
\hline Baixadas & 303.989 & 2,4 & 462.325 & 3,2 & 700.842 & 4,4 & 4,9 & 4,2 & 10,0 & 14,9 \\
\hline Metropolitana & 10.389 .441 & 81,1 & 11.546 .023 & 80,2 & 12.578 .485 & 78,7 & 1,2 & 0,9 & 73,0 & 64,6 \\
\hline Sul & 803.752 & 6,3 & 933.983 & 6,5 & 1.062 .237 & 6,6 & 1,7 & 1,3 & 8,2 & 8,0 \\
\hline Rio de Janeiro & 12.807.195 & 100,0 & 14.392 .106 & 100,0 & 15.989 .929 & 100,0 & 1,3 & 1,1 & 100,00 & 100,00 \\
\hline
\end{tabular}

Fonte: IBGE - Censos Demográficos, 1991, 2000 e 2010.

Segundo Brito (2002), no contexto das migraçóes internas no Brasil, nos anos 1940-1950, 1950-1960 e 1960-1970, o Rio de Janeiro destacava-se, ao lado de São Paulo, do Paraná e da região Centro-Oeste, entre as principais áreas de atração populacional. Porém, como empiricamente demonstrado pelo autor, o estado foi perdendo seu poder de atração populacional, principalmente em decorrência da perda relativa de dinamismo econômico. De acordo com dados de migração de última etapa, apresentados pelo autor, entre 1960-1970 o saldo migratório estadual foi da ordem de 1.030.464 indivíduos, reduzindo-se para 392.614 imigrantes entre 1970-1980 e chegando a apresentar saldo migratório negativo, estimado em -44.100 indivíduos, entre 1981-1991.

Considerando os quesitos de migração nos Censos Demográficos de 2000 e 2010, estimaram-se indicadores da migração de última etapa para o estado do Rio de Janeiro, cujos resultados estão dispostos na Tabela 2. Nas décadas de 1990 e 2000, o Rio atraiu pouco mais de 6\% dos imigrantes internos, não mais se destacando entre as principais áreas de atração populacional. Assim, se, por um lado, o estado voltou a apresentar saldos migratórios positivos, por outro é preciso considerar que são reduzidos e que o impacto dos movimentos migratórios sobre o ritmo de crescimento populacional estadual, dado pela Taxa Líquida de Migração, também é baixo e, inclusive, decrescente. 
Tabela 2. Rio de Janeiro: indicadores da migração interestadual (1990-2000 e 2000-2010)

\begin{tabular}{|l|r|r|r|r|}
\hline Período & Imigrantes & Emigrantes & $\begin{array}{c}\text { Saldo } \\
\text { migratório }\end{array}$ & $\begin{array}{c}\text { Taxa Líquida } \\
\text { de Migração }\end{array}$ \\
\hline $1991-2000$ & 749.087 & 620.496 & 128.591 & 0,89 \\
$2000-2010$ & 676.527 & 565.777 & 110.750 & 0,69 \\
\hline
\end{tabular}

Fonte: IBGE - Censos Demográficos, 2000 e 2010.

Internamente, os ritmos de crescimento populacional variam de modo significativo entre as mesorregiōes de planejamento. Como se pode notar na Tabela 1, a mesorregião Metropolitana, apesar de concentrar a maior parcela da população $(78,67 \%$, em 2010$)$ e de ser a maior responsável pelo incremento absoluto da população estadual (64,62\%, em 2010), é a que cresce mais lentamente (0,86\%, entre 2000-2010). O Centro e o Noroeste Fluminense também apresentaram crescimento populacional reduzido $(0,62 \%$ e $0,64 \%$, respectivamente, entre $2000-2010)$, mas, diferentemente da mesorregião Metropolitana, contribuíram apenas infimamente para o incremento absoluto e concentraram apenas uma parcela irrisória da população estadual.

A Baixada Litorânea é a mesorregião de crescimento populacional mais acelerado. Entre 19912000, sua taxa média anual de crescimento foi da ordem de 4,86\%, reduzindo-se (mas, ainda assim, permanecendo elevada) para 4,25\% no período 2000-2010. Sua participação relativa no incremento absoluto subiu de 9,99\%, entre 1991-2000, para 14,93\%, entre 2000-2010. Também se destacam pelos ritmos de crescimento as mesorregiōes Sul e Norte Fluminense. Note, no entanto, o arrefecimento do ritmo de crescimento do Sul - de 1,71\%, entre 1991-2000, para 1,30\% entre 2000-2010 - e o recrudescimento do ritmo de crescimento do Norte, de 1,53\% para 1,97\%.

Como se pode notar na Figura 1, a maioria dos municípios fluminenses apresentou, entre 20002010, taxas de crescimento bastante baixas, ressaltando-se que sete deles - Cantagalo e Santa Maria Madalena no Centro; Itaocara, Laje do Muriaé, Miracema e Natividade, no Noroeste; e São Francisco do Itabapoana, no Norte - apresentaram taxas negativas, ou seja, reduziram sua população em termos absolutos. Observe, ainda, que a principal frente de expansão urbana concentra-se, atualmente, na faixa litorânea norte, estendendo-se de Maricá, na mesorregião Metropolitana, a Quissamã, no Norte Fluminense. 
Figura 1. Rio de Janeiro: taxas de crescimento populacional médio anual, segundo o município (2000-2010)

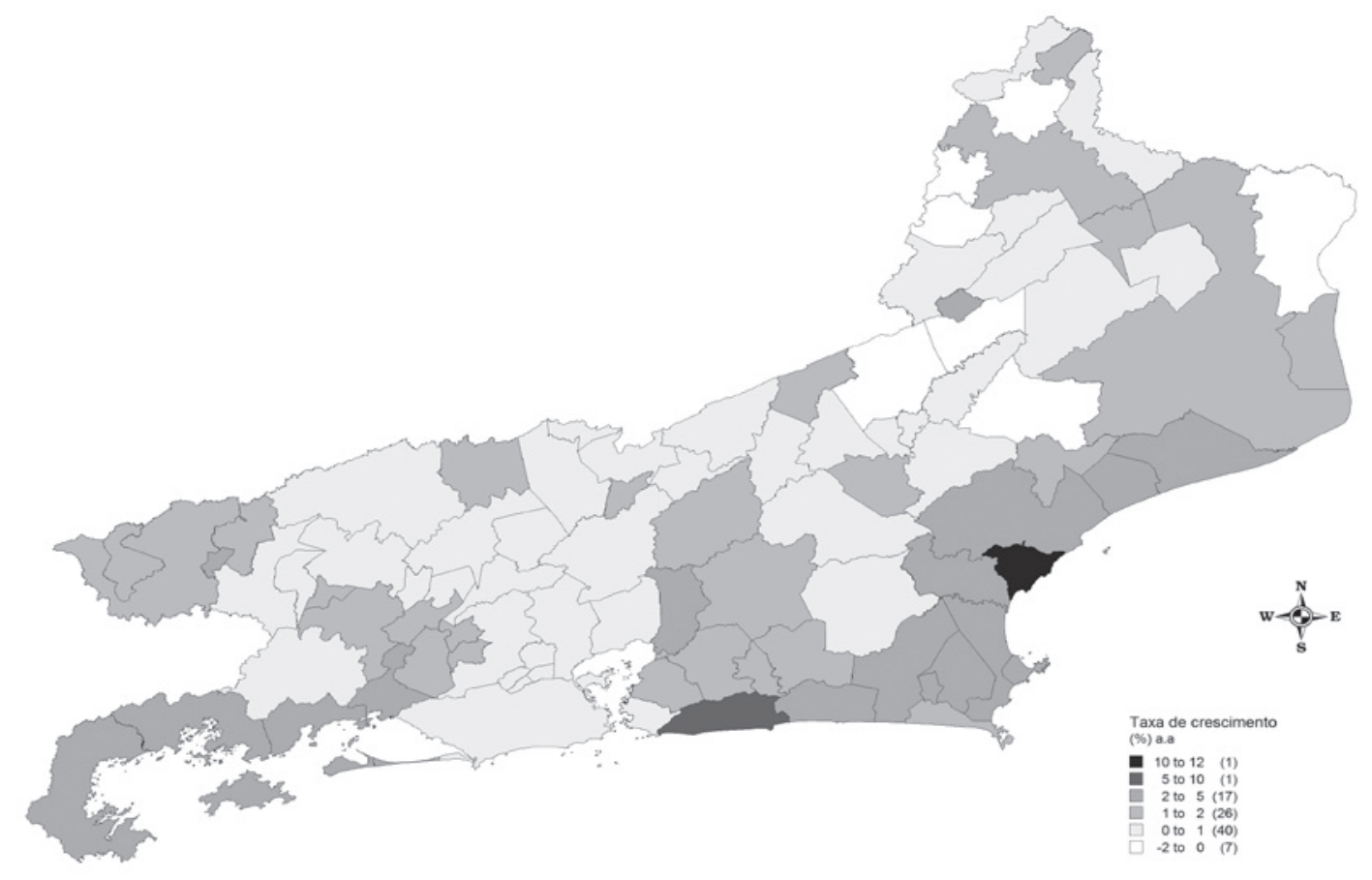

Fonte: IBGE - Censo Demográfico, 2000 e 2010.

Como se pretende analisar a reprodução do capital sob a ótica da geografia da acumulação, entre os municípios localizados na principal faixa de expansão urbana, interessa-nos particularmente aqueles considerados produtores de petróleo, quais sejam: Arraial do Cabo, Armação dos Búzios e Cabo Frio, na aglomeração urbana de Cabo Frio; Macaé, Carapebus, Casimiro de Abreu e Rio das Ostras, na aglomeração urbana de Macaé; e Campos e São João da Barra, na aglomeração urbana de Campos dos Goytacazes. Ficaram excluídos os municípios não produtores: São Pedro da Aldeia e Conceição de Macabu, nas aglomeraçôes urbanas de Cabo Frio e Macaé, respectivamente.

$\mathrm{Na}$ Tabela 3, é possível observar os ritmos de crescimento dos municípios selecionados, assim como a distribuição espacial da população e a participação relativa de cada município no incremento absoluto dessa grande extensão urbana. Note-se que mesmo aqueles municípios com ritmos de crescimento populacional mais lento cresceram a uma taxa superior à média estadual, e que os municípios que mais contribuem para o crescimento acelerado dessa expansão urbana são Macaé (24,6\%), Rio das Ostras (22,9\%), Cabo Frio (19,7\%) e Campos dos Goytacazes (18,7\%). O incremento populacional desses municípios explica praticamente $86 \%$ do incremento populacional de toda essa extensão urbana e é justamente neles que se concentram, praticamente, $86 \%$ da população residente, ressaltando que, em 2010, 41,4\% da população residia em apenas um município: Campos dos Goytacazes. 
Tabela 3. Municípios selecionados: população, taxa de crescimento e participação relativa no incremento absoluto (2000-2010)

\begin{tabular}{|c|c|c|c|c|c|c|}
\hline \multirow{2}{*}{ Municípios Selecionados } & \multicolumn{4}{|c|}{ População } & \multirow{2}{*}{$\begin{array}{c}\text { Taxa de } \\
\text { crescimento } \\
(2000-2010)\end{array}$} & \multirow{2}{*}{$\begin{array}{l}\text { Participação } \\
\text { relativa no } \\
\text { incremento }\end{array}$} \\
\hline & 2000 & $\%$ & 2010 & $\%$ & & \\
\hline Armação dos Búzios & 18.204 & 2,2 & 27.560 & 2,5 & 4,2 & 3,1 \\
\hline Arraial do Cabo & 23.877 & 2,9 & 27.715 & 2,5 & 1,5 & 1,3 \\
\hline Cabo Frio & 126.828 & 15,5 & 186.227 & 16,6 & 3,9 & 19,7 \\
\hline Carapebus & 8.666 & 1,1 & 13.359 & 1,2 & 4,4 & 1,6 \\
\hline Campos dos Goytacazes & 407.168 & 49,8 & 463.731 & 41,4 & 1,3 & 18,7 \\
\hline Casimiro de Abreu & 22.152 & 2,7 & 35.347 & 3,2 & 4,8 & 4,4 \\
\hline Macaé & 132.461 & 16,2 & 206.728 & 18,5 & 4,6 & 24,6 \\
\hline Quissamã & 13.674 & 1,7 & 20.242 & 1,8 & 4,0 & 2,2 \\
\hline Rio das Ostras & 36.419 & 4,5 & 105.676 & 9,4 & 11,2 & 22,9 \\
\hline São João da Barra & 27.682 & 3,4 & 32.747 & 2,9 & 1,7 & 1,7 \\
\hline Total & 817.131 & 100,0 & 1.119 .332 & 100,0 & 3,2 & 100,0 \\
\hline
\end{tabular}

Fonte: IBGE - Censos Demográficos, 2000 e 2010.

Como se mencionou, há uma influência significativa dos movimentos migratórios na definição dessa área de expansão urbana e nos ritmos de crescimento populacional desses municípios.

Para analisarmos as migrações interestaduais, identificamos, nos Censos Demográficos das UFs brasileiras (exclusive Rio de Janeiro) e do Distrito Federal, os emigrantes dos municípios selecionados, ou seja, todos os indivíduos que, no momento do recenseamento, informaram um dos municípios selecionados como o de residência anterior e, no Censo Demográfico do Rio de Janeiro, os imigrantes, ou seja, todos os indivíduos que, no momento do recenseamento, informaram como residência anterior algum município de outro estado brasileiro ou do Distrito Federal. Os resultados encontram-se sumarizados na Tabela 4.

Tabela 4. Municípios selecionados: indicadores das migrações interestaduais (2000-2010)

\begin{tabular}{|l|r|r|r|r|}
\hline \multirow{2}{*}{ Municípios selecionados } & \multicolumn{4}{|c|}{ Migração Interestadual } \\
\cline { 2 - 6 } & \multicolumn{1}{|c|}{$\mathrm{I}$} & \multicolumn{1}{c|}{ E } & \multicolumn{1}{c|}{ SM } & \multicolumn{1}{c|}{ TLM } \\
\hline Armação dos Búzios & 2.319 & 830 & 1.489 & 5,4 \\
Arraial do Cabo & 1.271 & 593 & 678 & 2,4 \\
Cabo Frio & 12.350 & 4.351 & 7.999 & 4,3 \\
Carapebus & 577 & 39 & 538 & 4,0 \\
Campos dos Goytacazes & 10.016 & 6.697 & 3.319 & 0,7 \\
Casimiro de Abreu & 1.967 & 293 & 1.674 & 4,7 \\
Macaé & 25.216 & 6.614 & 18.602 & 9,0 \\
Quissamã & 528 & 74 & 454 & 2,2 \\
Rio das Ostras & 11.887 & 2.073 & 9.814 & 9,3 \\
São João da Barra & 1.378 & 119 & 1.259 & 3,8 \\
Total & 67.509 & 21.683 & 45.826 & 4,1 \\
\hline
\end{tabular}

Fonte: IBGE - Censo Demográfico (2010). 
No contexto das migraçōes interestaduais, esses municípios receberam, no período 2000-2010, um total de 67.509 imigrantes e perderam para outras UFs e o Distrito Federal um total de 21.683 habitantes, portanto o saldo migratório apresentou-se positivo e da ordem de 45.826 pessoas. Entre os municípios que mais atraíram imigrantes, destacam-se: Macaé (37,4\%), Cabo Frio $(18,3 \%)$, Rio das Ostras (17,6\%) e Campos dos Goytacazes (14,6\%), respectivamente. Esses mesmos municípios se destacam também como os maiores expulsores de população na seguinte ordem: Campos dos Goytacazes (30,9\%), Macaé (30,5\%), Cabo Frio (20,1\%) e Rio das Ostras (9,6\%).

Ainda no contexto das migraçôes interestaduais, é importante ressaltar que todos os municípios apresentaram saldos migratórios positivos e que as migraçōes internas exerceram, naquele período, notável influência no crescimento populacional de Rio das Ostras (9,3\%), Macaé (9,0\%), Armação dos Búzios (5,4\%) e Casimiro de Abreu (4,7\%).

Para analisarmos a influência das migraçóes intraestaduais nesse processo, confeccionamos duas matrizes origem-destino, levando em conta: (1) apenas as trocas populacionais entre os municípios selecionados; (2) as trocas populacionais entre eles e os demais municípios fluminenses. Os resultados encontram-se sumarizados na Tabela 5, e estão divididos conforme os tipos - (1) e (2) antes definidos.

Tabela 5. Municípios selecionados: indicadores das migraçôes intraestaduais (2000-2010)

\begin{tabular}{|c|c|c|c|c|c|c|c|c|c|c|c|c|}
\hline \multirow{2}{*}{ Municípios selecionados } & \multicolumn{4}{|c|}{ Migração Intraestadual (1) } & \multicolumn{4}{|c|}{ Migração Intraestadual (2) } & \multicolumn{4}{|c|}{ Migração Intraestadual Total } \\
\hline & $\mathrm{I}$ & $\mathrm{E}$ & SM & TLM & $\mathrm{I}$ & $\mathrm{E}$ & $\mathrm{SM}$ & TLM & $\mathrm{I}$ & $\mathrm{E}$ & $\mathrm{SM}$ & TLM \\
\hline Armação dos Búzios & 1.698 & 1.036 & 662 & 2,4 & 4.412 & 1.358 & 3.054 & 11,1 & 6.110 & 2.394 & 3.716 & 13,5 \\
\hline Arraial do Cabo & 1.277 & 1.259 & 18 & 0,1 & 4.579 & 1.635 & 2.944 & 10,6 & 5.856 & 2.894 & 2.962 & 10,7 \\
\hline Cabo Frio & 6.401 & 4.742 & 1.659 & 0,9 & 36.213 & 14.612 & 21.601 & 11,6 & 42.614 & 19.354 & 23.260 & 12,5 \\
\hline Carapebus & 1.535 & 531 & 1.004 & 7,5 & 1.255 & 177 & 1.078 & 8,1 & 2.790 & 708 & 2.082 & 15,6 \\
\hline Campos dos Goytacazes & 4.531 & 18.141 & -13.610 & $-2,9$ & 13.006 & 14.461 & -1.455 & $-0,3$ & 17.537 & 32.602 & -15.065 & $-3,2$ \\
\hline Casimiro de Abreu & 2.873 & 2.087 & 786 & 2,2 & 7.280 & 1.475 & 8.045 & 22,8 & 10.153 & 1.322 & 8.831 & 25,0 \\
\hline Macaé & 9.137 & 10.544 & -1.407 & $-0,7$ & 23.202 & 8.565 & 14.637 & 7,1 & 32.339 & 19.109 & 13.230 & 6,4 \\
\hline Quissamã & 1.480 & 672 & 808 & 4,0 & 1.820 & 487 & 1.333 & 6,6 & 3.300 & 1.159 & 2.141 & 10,6 \\
\hline Rio das Ostras & 11.868 & 3.551 & 8.317 & 7,9 & 36.566 & 3.781 & 32.785 & 31,0 & 48.434 & 7.332 & 41.102 & 38,9 \\
\hline São João da Barra & 2.976 & 1.213 & 1.763 & 5,4 & 1.191 & 352 & 839 & 2,6 & 4.167 & 1.565 & 2.602 & 7,9 \\
\hline Total & 43.776 & 43.776 & 0 & 0,0 & 129.524 & 46.903 & 84.861 & 7,6 & 173.300 & 88.439 & 84.861 & 7,6 \\
\hline
\end{tabular}

Fonte: IBGE - Censo Demográfico (2010).

Como era de se esperar, as migrações intraestaduais têm uma importância significativamente maior no processo de expansão desses municípios dos respectivos aglomerados urbanos e, consequentemente, sobre o processo de acumulação capitalista na Bacia de Campos. Se, por um lado, as mudanças de residência observadas entre os municípios selecionados, estimadas em 43.776 indivíduos para o período 2000-2010, não implicam ganho populacional líquido para essa extensão urbana como um todo, por outro lado é preciso salientar seu papel na redistribuição espacial da população residente. Isso ocorre como reflexo dos processos internos de seletividade populacional, de seletividade migratória e da dinâmica dos mercados imobiliários e de trabalho, assim como de algum processo, ainda que incipiente, de especialização dos espaços urbanos municipais, no contexto dos aglomerados urbanos. Os fluxos migratórios entre os municípios selecionados podem ser observados na Matriz Origem-Destino 1. 
Matriz Origem-Destino 1. Municípios selecionados: fluxos migratórios de última etapa (2000-2010)

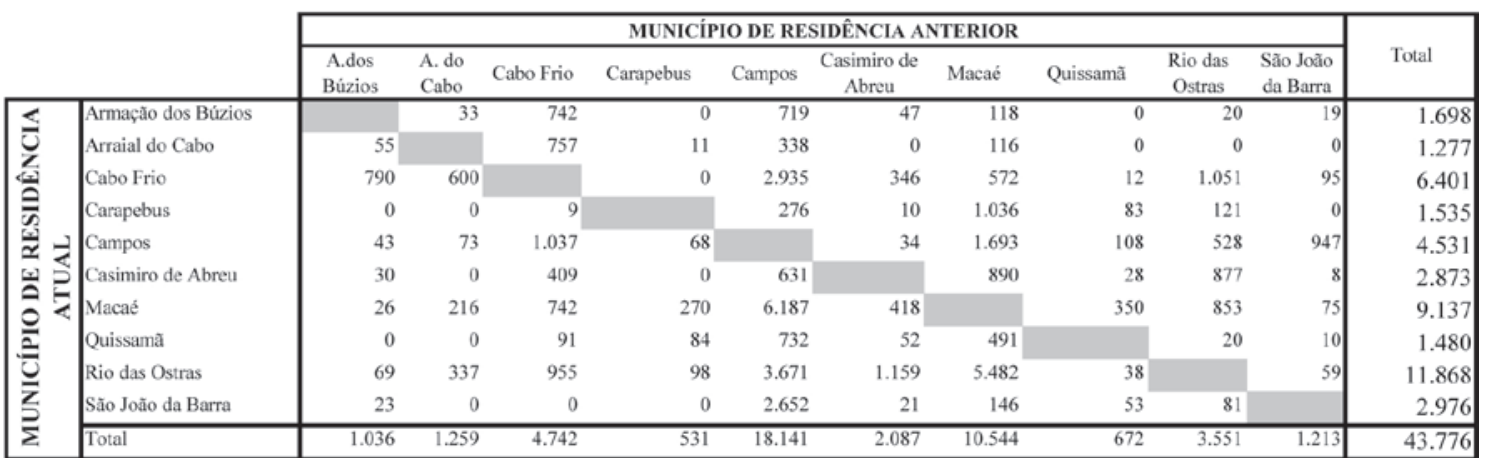

Fonte: IBGE - Censo Demográfico, 2010.

No contexto intrarregional (Matriz Origem-Destino 1), Campos dos Goytacazes e Macaé aparecem como fornecedores líquidos de população, e os demais municípios, notadamente Rio das Ostras, São João da Barra, Cabo Frio e Carapebus, aparecem como receptores líquidos. Ressalte-se que os maiores impactos dessas mudanças de residência sobre os ritmos de crescimento municipais se verificam em Rio das Ostras, Carapebus e Quissamã, nas proximidades de Macaé; e em São João da Barra, limítrofe a Campos.

Considerando-se as mudanças de residência entre os municípios selecionados e os demais municípios fluminenses, o Censo Demográfico de 2010, cujos resultados estão apresentados na Tabela 5, indica um total de 129.524 imigrantes, 46.903 emigrantes e um ganho populacional líquido da ordem de 84.861 indivíduos. Como principais destinos, destacam-se: Rio das Ostras $(28,2 \%)$, Cabo Frio (28,0\%), Macaé (17,0\%) e Campos dos Goytacazes (10,0\%). Esses mesmos municípios destacam-se entre as principais origens emigratórias.

Nas últimas colunas da Tabela 5, é possível analisar as migrações intraestaduais totais. Apenas Campos dos Goytacazes apresenta saldo migratório negativo e, inclusive, bastante elevado (-15.065 habitantes), o que indica que, nesse município, os movimentos migratórios, ao contrário do senso comum, têm contribuído para arrefecer seu ritmo de crescimento. Para os demais municípios, fica evidente, tendo em vista a magnitude das Taxas Líquidas de Migração (TLM), o papel das migraçóes intraestaduais para a aceleração do crescimento populacional, sendo Rio das Ostras e Casimiro de Abreu os casos mais notáveis. A TLM indica que, em 2010, a população de Rio das Ostras encontrava-se em torno de $48 \%$ maior do que aquela que seria verificada na ausência de movimentos migratórios intraestaduais; para Casimiro de Abreu, esse valor ficou em torno de $25 \%$.

Em termos globais, as aglomerações urbanas estudadas receberam, no período de 2000 a 2010, 240.809 imigrantes e registraram um total de 110.122 emigrantes. Em termos líquidos, essa extensão urbana recebeu 130.687 novos habitantes. Os saldos migratórios totais e a influência das migrações sobre os ritmos de crescimento populacional podem ser apreciados nas Figuras 2 e 3 , respectivamente. 
A importância da mobilidade populacional para a acumulação capitalista

Figura 2. Municípios selecionados: saldo migratório de última etapa (2010)

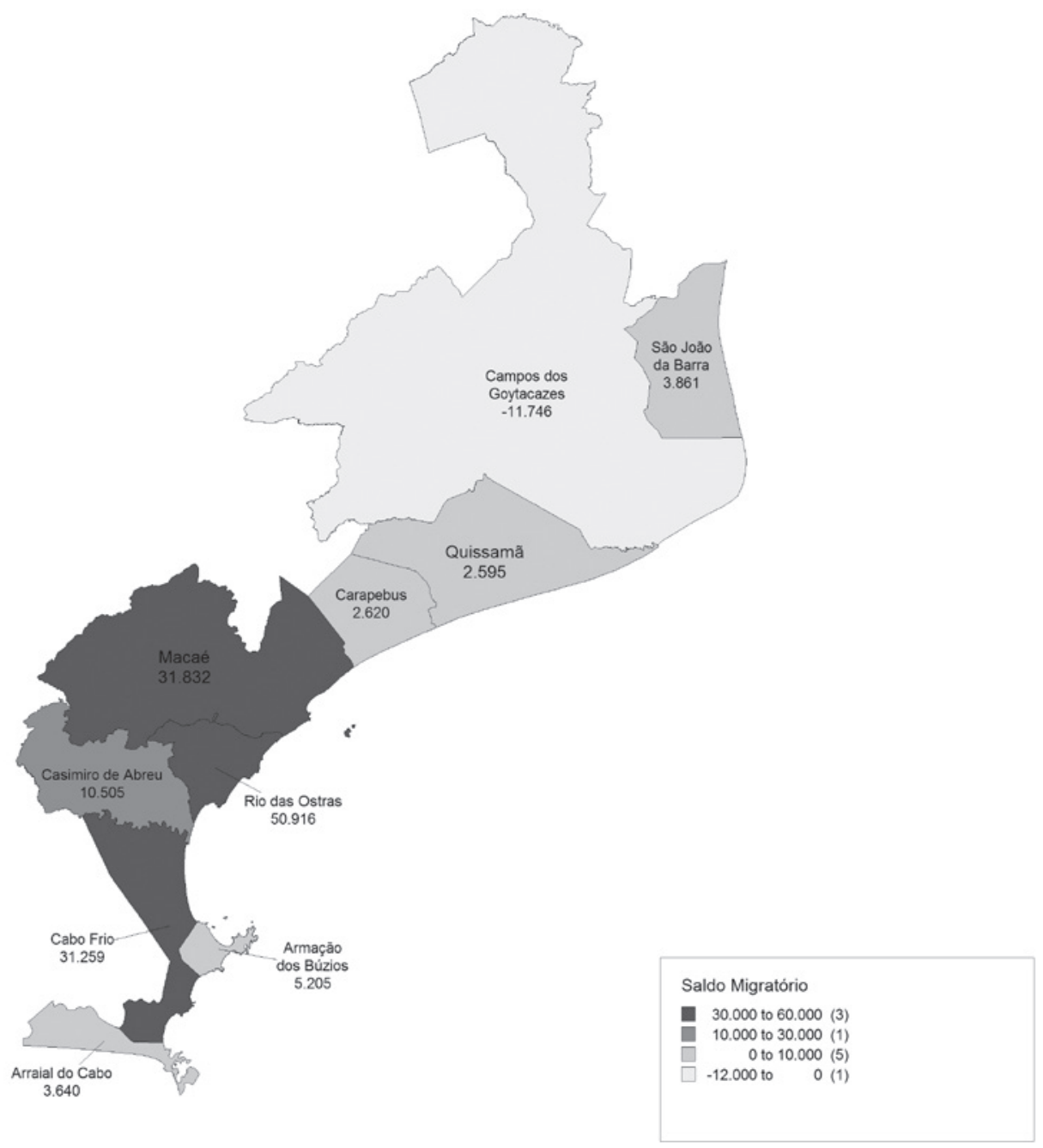

Fonte: IBGE - Censo Demográfico, 2010.

Note-se, na Figura 3, que, à exceção de Campos dos Goytacazes, as migrações são de fundamental importância para a definição do ritmo de crescimento populacional dos municípios e, portanto, para toda a extensão urbana. 
Figura 3. Municípios selecionados: taxa líquida de migração (2010)

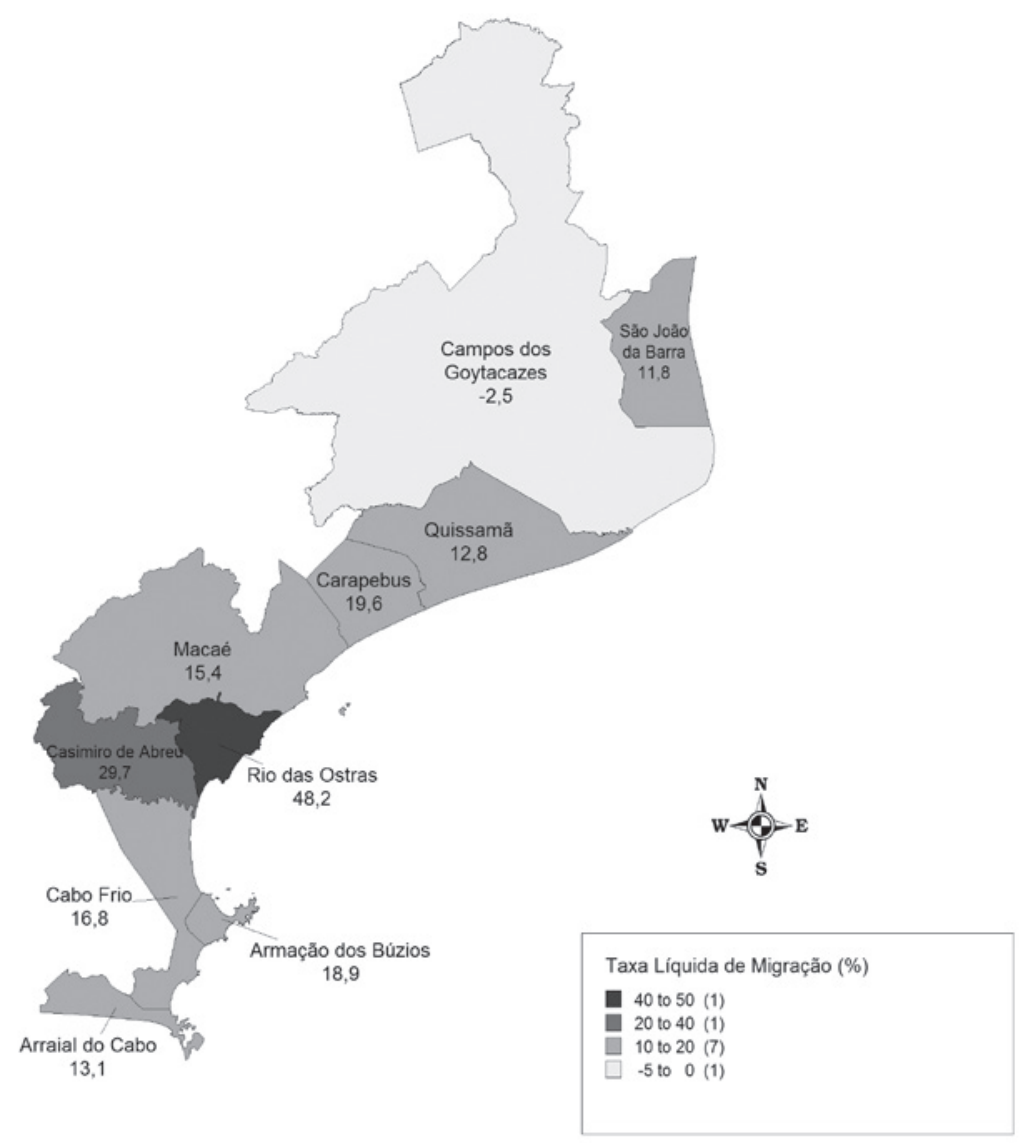

Fonte: IBGE - Censo Demográfico, 2010.

Campos dos Goytacazes, o maior município em extensão territorial do estado do Rio de Janeiro e o maior beneficiário das rendas petrolíferas (royalties e participaçôes especiais), é um caso curioso: apresenta saldo migratório positivo, no contexto das migrações interestaduais, mas, em função das migraçôes intraestaduais, significativamente mais volumosas, o saldo migratório total do município é, diferentemente do que acredita o senso comum, negativo e elevado (da ordem de 11.746 indivíduos).

Outro caso interessante é o de Macaé, base de operaçōes da Petrobras e das demais empresas petrolíferas e parapetrolíferas: apesar de apresentar um saldo migratório total positivo e inclusive bastante elevado, o saldo migratório negativo em relação aos demais municípios selecionados sugere uma seletividade migratória, impulsionada, por um lado, pelo mercado imobiliário do próprio município, caracterizado pelo alto preço da terra, e, por outro, pelos mercados imobiliários de Rio das Ostras, Casimiro de Abreu e Carapebus, que ainda praticam preços relativamente mais baixos. Além disso, a realização de investimentos na estrutura viária que liga esses municípios favorece a emigração nessas 


\section{A importância da mobilidade populacional para a acumulação capitalista}

direções, na medida em que permite a realização do movimento pendular por motivo de trabalho, em espaço de tempo relativamente curto.

Cabo Frio, município turístico na Região dos Lagos, mas na Franja Metropolitana, também apresentou saldo migratório positivo elevado. Nesse caso, o setor de serviços, principalmente as possibilidades de emprego no setor de turismo, atrai muitos imigrantes. Também se aplicam a essa mesma situação os municípios de Armação dos Búzios e Arraial do Cabo.

Finalmente, cabe mencionar o caso do município de Rio das Ostras, que já se encontra conurbado a Macaé. No limite entre esses municípios, mas no território de Rio das Ostras, foi instalada, uma Zona Especial de Negócios (ZEN), no sentido de favorecer economias de escala, inclusive com a promoção de vantagens locacionais. Nesse ponto, é interessante notar que, apesar de estar se desenvolvendo um mercado de trabalho em Rio das Ostras, este reflete mais a dinâmica da indústria do petróleo do que eventuais políticas municipais de diversificação industrial e produtiva. Isso significa dizer que esse mercado de trabalho é altamente dependente do dinamismo econômico da indústria do petróleo. Atente-se para o fato de que esse desenvolvimento é positivo, na medida em que estimula a criação de novos postos de trabalho, mas, por outro lado, a dependência econômica em torno de um único setor expõe esses municípios a uma maior vulnerabilidade, mediante situações adversas como as que estão ocorrendo na atualidade, devido à redução do preço internacional do barril do petróleo e à operação Lava-Jato.

Os preços praticados pelo mercado imobiliário, o desenvolvimento do mercado de trabalho do município e a proximidade espacial com Macaé tornam essa uma importante área de atração para os imigrantes inter e intraestaduais. Seu poder de atração apresenta-se tão elevado que, na década de 2000-2010, recebeu mais imigrantes do que Macaé e Cabo Frio. Como seu poder de retenção populacional também é elevado, o ganho populacional líquido do município, no período considerado, foi de mais de cinquenta mil habitantes e a TLM foi de 48,2\%.

Sob a perspectiva de reprodução e acumulação capitalista, os movimentos migratórios só podem ser considerados funcionais e, portanto, positivos se os imigrantes atraídos pelas possibilidades de emprego no mercado de trabalho forem suficientemente qualificados para nele ingressarem; caso contrário, os acirrados processos de seletividade migratória provocarão volumosos fluxos de (re)emigração. Nos aglomerados urbanos em questão, pode-se afirmar que são elevados os poderes de atração e retenção populacional, bem como a redistribuição espacial da população no território.

Souza, Terra e Campos (2015) verificaram o papel da mão de obra natural e migrante no processo de reestruturação do mercado de trabalho na região da Organização dos Municípios Produtores de Petróleo (Ompetro), que inclui, além de todos os municípios selecionados, o município de Niterói. Nesse estudo, os autores analisaram os movimentos migratórios de data-fixa e partiram do pressuposto de que são significativas as diferenças entre a qualidade da mão de obra dos não migrantes (aqueles que nasceram em um município e nunca residiram em outro) e dos imigrantes (incluindo os naturais que, tendo residido em outro município, retornam ao município de nascimento), estes divididos em três categorias: intraestaduais, interestaduais e internacionais.

Em primeiro lugar, os autores avaliaram os indicadores de escolaridade da população, segundo o estrato populacional e o status migratório, para os períodos 1986-1991; 1995-2000 e 2005-2010, considerando apenas os indivíduos na faixa etária de 20 anos ou mais, à exceção dos adultos matri- 
culados em programas de alfabetização. Assim, inicialmente, observaram a tendência para a elevação do grau de alfabetização da população e que, em todos os períodos, esse era mais elevado entre os migrantes, apesar das diferenças entre os status migratórios.

Tabela 6. Ompetro: grau de alfabetização segundo o estrato populacional e o status migratório (19861991, 1995-2000 e 2005-2010)

\begin{tabular}{|l|r|r|r|r|}
\hline & \multicolumn{3}{|c|}{ Imigrantes } & \multirow{2}{*}{ Período } \\
\cline { 2 - 4 } & Intraestaduais & \multicolumn{1}{|c|}{ Interestaduais } & Internacionais & Nano migrantes \\
\hline $1986-1991$ & 92 & 90,7 & 100 & 85,3 \\
$1995-2000$ & 95,1 & 94 & 99,2 & 91,8 \\
$2005-2010$ & 97,8 & 96,5 & 100 & 94,3 \\
\hline \hline
\end{tabular}

Fonte: Souza, Terra e Campos, 2015.

Através dos Censos Demográficos de 1991 e 2000, os autores analisaram a distribuição da população segundo a variável anos de estudo e estimaram a escolaridade média da população segundo o estrato populacional (não migrante versus migrante) e o status migratório (migrante intraestadual, interestadual e internacional).

Para o período 1986-1991, verificaram que 51\% dos não migrantes eram considerados analfabetos funcionais, estimando em 7,2 anos de estudo a escolaridade média desse estrato populacional. De forma complementar, analisando as mesmas informações para os imigrantes, detectaram um nível menor de analfabetismo funcional (35,6\% entre os imigrantes intraestaduais e 33,4\% entre os interestaduais) e uma escolaridade média mais elevada (8,7 e 9,1 anos, respectivamente).

O Censo de 2000 aponta a redução do analfabetismo funcional para 36,8\% dos não migrantes, $26,2 \%$ dos imigrantes intraestaduais e $25,3 \%$ dos imigrantes interestaduais; e a elevação da escolaridade média dos não migrantes para 7,9 anos de estudo e dos migrantes intraestaduais para 9,1 anos de estudo. E, mesmo diante da impossibilidade imposta pelo Censo Demográfico de 2010, que não permite estimar a escolaridade média, Souza, Terra e Campos (2015) inferiram, a partir da distribuição relativa da variável nivel de instrução segundo o estrato populacional e o status migratório: (i) a elevação da escolaridade média de todos os estratos populacionais e status migratório; (ii) a persistência das diferenças, ainda que em menor magnitude, entre as escolaridades médias dos imigrantes e dos naturais, permanecendo estes últimos com níveis de escolaridade mais baixos; (iii) a convergência da escolaridade do migrante intraestadual para a do migrante interestadual, já apontada pelos sensos anteriores.

Esses resultados revelam, por um lado, o esforço da mão de obra não migrante em sair da margem desse mercado de trabalho, cuja inserção em uma posição relativamente melhor só é possível para os mais qualificados, tendo em vista o uso cada vez mais intenso de tecnologias sofisticadas no processo produtivo. Por outro lado, revelam também a seletividade cada vez mais intensa desse mercado de trabalho, no qual apenas os indivíduos mais qualificados têm sobrevivido à reemigração. Na prática, as diferenças de qualificação profissional se materializam nas condições de inserção e permanência dos indivíduos no mercado de trabalho, assim como em seus rendimentos médios mensais. 


\section{A importância da mobilidade populacional para a acumulação capitalista}

Apesar de a maioria dos trabalhadores ser empregada com carteira assinada, é notória a elevada participação de informais e por conta própria (termo, no contexto brasileiro, muitas vezes associado a trabalho precário) naquele mercado de trabalho: 38,72\% dos não migrantes; 36,24\% dos imigrantes intraestaduais; 32,93\% dos imigrantes interestaduais; e 35,22\% dos imigrantes estrangeiros. Esses resultados comprovam que muitos trabalhadores ficam, de fato, à margem do processo de reprodução do capital. Como abrangem indivíduos de diferentes estratos populacionais e condições socioeconômicas, infere-se que constituem um diversificado reservatório de força de trabalho - nas palavras de Marx, um "exército industrial de reserva" - necessário para manter os salários em baixos patamares, em todos os setores de atividade, comparativamente a uma situação de escassez de oferta de mão de obra.

Souza, Terra e Campos (2015) detectaram que as formas de inserção no mercado de trabalho são significativamente diferenciadas segundo o estrato populacional. Os não migrantes exercem, em sua maioria, ocupaçôes que demandam trabalhadores menos qualificados e, portanto, percebem rendimentos mensais menores, estimados, em média, em $\mathrm{R} \$ 1.456,57$ (a preços de 2010). Segundo os autores, há diferenças significativas entre as ocupaçôes e os rendimentos dos imigrantes, tanto em relação aos não migrantes como em relação ao status migratório. Em linhas gerais, afirmam os autores, predominam imigrantes internacionais e intraestaduais nas ocupações com maior qualificação, e imigrantes interestaduais naquelas com menor qualificação. Os rendimentos médios foram estimados em $\mathrm{R} \$ 3.955,91 ; \mathrm{R} \$ 1.950,48$; e $\mathrm{R} \$ 2.047,26$, respectivamente.

Além da mão de obra imigrante, o trabalhador pendular tem-se tornado cada vez mais imprescindível para a reprodução do capital na Bacia de Campos. Aliás, é interessante salientar que, para um número cada vez maior de indivíduos, verifica-se a dissociação entre o lugar de trabalho e o lugar de residência, e esses movimentos, que antes se restringiam basicamente às regióes metropolitanas, têm sido observados com frequência cada vez maior nas áreas urbanas não metropolitanas. Segundo Marandola Jr. e Ojima (2014, p. 186), a intensificação desses movimentos está "intimamente ligada às transformações na vida urbana e nas instituições, numa regionalização do cotidiano, que acompanha a dispersão de atividades industriais, de lazer, de comércio e de empreendimentos imobiliários".

No Censo Demográfico de 2010, há dois conceitos implícitos de pendularidade: um mais amplo, que considera pendular todo indivíduo que trabalha em um município diferente do município de residência, sem levar em conta a periodicidade do deslocamento, e outro mais estrito, que se refere "àquele realizado por indivíduos que trabalham em municípios diferentes do de residência, e que retornam para casa diariamente, independentemente do tempo habitualmente gasto nesse deslocamento" (Souza et al., 2013, p. 8).

Tendo em vista as características do mercado de trabalho da Bacia de Campos, que tem um regime de contratação por turnos de um número significativo de trabalhadores no segmento usptream da indústria do petróleo, optou-se por se trabalhar com o conceito mais amplo e incluir a pendularidade de longa distância (interestadual).

Considerando-se a pendularidade interestadual, verifica-se a entrada de 12.329 trabalhadores, oriundos principalmente da própria Região Sudeste, mais notadamente do Espírito Santo e de Minas Gerais, mas também das regiões Norte, Nordeste, Centro-Oeste e Sul do país (Tabela 7). A saída de trabalhadores pendulares desses municípios para outros estados brasileiros é pequena, prevalecendo como destinos a própria Região Sudeste. À exceção de Arraial do Cabo, Carapebus, Casimiro de 
Abreu e Quissamã, em todos os outros municípios o saldo pendular é positivo, mas Macaé é o principal receptor dessa mão de obra - absorveu 74,5\% dos trabalhadores pendulares interestaduais - seguido, de longe, por Campos, que absorveu 16,2\%.

Tabela 7. Municípios selecionados: indicadores da mobilidade pendular interestadual, segundo o município selecionado, 2010

\begin{tabular}{|l|r|r|r|}
\hline \multirow{2}{*}{ Municípios selecionados } & \multicolumn{3}{|c|}{ Interestadual } \\
\cline { 2 - 4 } & Entradas & Saídas & Saldo Pendular \\
\hline Armação de Búzios & 128 & 0 & 128 \\
Arraial do Cabo & 2 & 29 & -27 \\
Cabo Frio & 548 & 340 & 208 \\
Carapebus & 6 & 31 & -25 \\
Campos dos Goytacazes & 1.994 & 818 & 1.176 \\
Casimiro de Abreu & 20 & 71 & -51 \\
Macaé & 9.190 & 395 & 8.795 \\
Quissamã & 25 & 32 & -7 \\
Rio das Ostras & 322 & 270 & 52 \\
São João da Barra & 92 & 34 & 58 \\
Total & 12.329 & 2.020 & 10.309 \\
\hline \hline
\end{tabular}

Fonte: IBGE - Censo Demográfico de 2010.

Seguindo o mesmo procedimento adotado para a análise dos movimentos migratórios intraestaduais, a pendularidade entre os municípios selecionados e os demais municípios fluminenses foi subdividida em: (1) intrarregional, que se restringe aos fluxos entre os municípios selecionados, (2) intraestadual parcial, que se refere a toda pendularidade entre os municípios selecionados e os demais municípios fluminenses e (3) intraestadual total.

Os fluxos intraestaduais são significativamente mais densos, sendo a pendularidade intrarregional maior que a pendularidade intraestadual parcial. No contexto intrarregional, apenas Macaé e Búzios apresentaram saldos pendulares positivos (23.364 e 5.061 trabalhadores, respectivamente). Em relação aos demais municípios, juntam-se a Macaé (com um saldo de 17.686 trabalhadores) e Búzios (1.421) os municípios de Cabo Frio (7.533), Campos dos Goytacazes (2.465) e Quissamã (181). 
Tabela 8. Municípios selecionados: indicadores da pendularidade intraestadual

\begin{tabular}{|c|c|c|c|c|c|c|c|c|c|}
\hline \multirow[b]{2}{*}{ Municípios selecionados } & \multicolumn{3}{|c|}{ Inter-regional } & \multicolumn{3}{|c|}{ Intraestadual Parcial } & \multicolumn{3}{|c|}{ Intraestadual Total } \\
\hline & Entradas & Saídas & $\begin{array}{c}\text { Saldo } \\
\text { Pendular }\end{array}$ & Entradas & Saidas & $\begin{array}{c}\text { Saldo } \\
\text { Pendular }\end{array}$ & Entradas & Saidas & $\begin{array}{c}\text { Saldo } \\
\text { Pendular }\end{array}$ \\
\hline Armação de Búzios & 5.370 & 309 & 5.061 & 1.625 & 204 & 1.421 & 6.995 & 513 & 6.482 \\
\hline Arraial do Cabo & 516 & 1.440 & -924 & 455 & 757 & -302 & 971 & 2.197 & -1.226 \\
\hline Cabo Frio & 2.105 & 10.475 & -8.370 & 11.259 & 3.726 & 7.533 & 13.364 & 14.201 & -837 \\
\hline Carapebus & 224 & 2.297 & -2.073 & 51 & 120 & -69 & 275 & 2.417 & -2.142 \\
\hline Campos dos Goytacazes & 2.345 & 8.072 & -5.727 & 5.273 & 2.808 & 2.465 & 7.618 & 10.880 & -3.262 \\
\hline Casimiro de Abreu & 1.462 & 3.752 & -2.290 & 730 & 951 & -221 & 2.192 & 4.703 & -2.511 \\
\hline Macaé & 24.272 & 908 & 23.364 & 18.537 & 851 & 17.686 & 42.809 & 1.759 & 41.050 \\
\hline Quissamã & 323 & 1.129 & -806 & 322 & 141 & 181 & 645 & 1.270 & -625 \\
\hline Rio das Ostras & 3.965 & 12.113 & -8.148 & 2.099 & 2.097 & 2 & 6.064 & 14.210 & -8.146 \\
\hline São João da Barra & 1.321 & 1.408 & -87 & 171 & 172 & -1 & 1.492 & 1.580 & -88 \\
\hline Total & 41.903 & 41.903 & 0 & 40.522 & 11.827 & 28.695 & 82.425 & 53.730 & 28.695 \\
\hline
\end{tabular}

Fonte: IBGE - Censo Demográfico de 2010.

No balanço da pendularidade intraestadual total (Tabela 8), assim como no cômputo da pendularidade total (interestadual + intraestadual total), saldos positivos se verificaram apenas em Macaé e Búzios. O primeiro, por concentrar as atividades da indústria petrolífera e parapetrolífera, e o segundo, pelo desenvolvimento do setor de turismo. Os resultados das tabelas 7 e 8 indicam que, além de atraírem muitos trabalhadores residentes em outros municípios, Macaé e Búzios têm uma grande capacidade de retenção da mão de obra residente. Isso porque, para cada trabalhador que saiu, entraram 24 em Macaé e 14 em Búzios. Segundo Souza e Terra (2015, p. 134),

em Macaé, os números da pendularidade indicam uma polarização regional. Esse município se destaca por atrair significativos fluxos não apenas de seus vizinhos, como também de outras UFs, incluindo aquelas mais distantes com as das regiões Norte e Nordeste. Apesar de Campos dos Goytacazes ser maior e apresentar uma economia mais diversificada, é Macaé que exerce uma importante centralidade: é em torno dele que se (re)organiza o tecido urbano regional.

A literatura nos aponta uma intrínseca relação entre movimentos pendulares e cidades-dormitório, definida por Miglioranza (apud Ojima et al., 2007) como a "cidade cujos habitantes saem, na maioria, para trabalhar em outra cidade, voltando apenas para dormir”. Ojima et al. (2007) consideram razoável supor que "o padrão de cidades-dormitório com baixo dinamismo econômico só passa a existir quando a proporção de movimentos pendulares é mais elevada, em torno de $40 \%$ da população ocupada”. De acordo com essa ótica, os resultados da Tabela 9 indicam uma cidade-dormitório Carapebus - entre os dez municípios selecionados, sugerindo uma possível transformação de Rio das Ostras e Casimiro de Abreu em cidades-dormitório nos próximos anos, caso se mantenham as atuais características econômicas, sociais e demográficas que influenciam tais deslocamentos. 
Tabela 9. Municípios selecionados: população economicamente ativa ocupada, segundo o local de trabalho (2010)

\begin{tabular}{|l|r|r|r|r|r|r|}
\hline \multirow{3}{*}{ Municípios Selecionados } & \multicolumn{6}{|c|}{ PEA ocupada RESIDENTE no município } \\
\cline { 2 - 7 } & \multicolumn{1}{|c|}{ Trabalha no próprio } & \multicolumn{1}{|c|}{ Trabalha em outro } & \multicolumn{2}{c|}{ PEA residente total } \\
\cline { 2 - 7 } & \multicolumn{1}{|c|}{ Absoluto } & \multicolumn{1}{c}{ Absoluto } & \multicolumn{1}{c|}{$\%$} & \multicolumn{1}{c|}{ Absoluto } & \multicolumn{1}{c|}{$\%$} \\
\hline Armação de Búzios & 13.039 & 95,90 & 557 & 4,10 & 13.596 & 100,00 \\
Arraial do Cabo & 10.249 & 81,52 & 2.324 & 18,48 & 12.573 & 100,00 \\
Cabo Frio & 69.346 & 81,78 & 15.445 & 18,22 & 84.791 & 100,00 \\
Carapebus & 3.604 & 59,26 & 2.478 & 40,74 & 6.082 & 100,00 \\
Campos dos Goytacazes & 173.998 & 93,07 & 12.958 & 6,93 & 186.956 & 100,00 \\
Casimiro de Abreu & 12.266 & 71,17 & 4.970 & 28,83 & 17.236 & 100,00 \\
Macaé & 100.154 & 97,41 & 2.658 & 2,59 & 102.812 & 100,00 \\
Quissamã & 7.198 & 83,48 & 1.424 & 16,52 & 8.622 & 100,00 \\
Rio das Ostras & 35.519 & 70,34 & 14.974 & 29,66 & 50.493 & 100,00 \\
São João da Barra & 12.724 & 88,21 & 1.700 & 11,79 & 14.424 & 100,00 \\
Total & 438.097 & 88,04 & 59.488 & 11,96 & 497.585 & 100,00 \\
\hline \hline
\end{tabular}

Fonte: IBGE - Censo Demográfico de 2010.

Utilizando o Censo Demográfico de 2010, Souza e Terra (2015) desenvolveram uma metodologia para estimar o nível de dependência de mão de obra exógena, definida como "toda a mão de obra ocupada não originária do município, conceito que abrange imigrantes e pendulares" (Souza e Terra, 2015, p. 135). Esse indicador é dado pela seguinte fórmula:

$$
N d=\frac{M D O_{\text {exógena }}}{M D O_{\text {ocupada }}} \times 100
$$

Onde:

$\mathrm{Nd}$ = Nível de dependência de mão de obra exógena

MDOexógena (indicador amplo): imigrante não natural entre duas datas fixas que declarou trabalhar no município de residência + indivíduo não residente que declarou trabalhar no município (pendular).

MDOexógena (indicador estrito): indivíduo não residente que declarou trabalhar no município (trabalhador pendular)

MDOocupada: indivíduo natural que reside e trabalha no município + indivíduo não natural residente no município, mas que o declarou como local de trabalho + indivíduo não residente que declarou trabalhar no município 


\section{A importância da mobilidade populacional para a acumulação capitalista}

Atente-se para o fato de que, no denominador, tem-se a população ocupada NO município que inclui todos os indivíduos que trabalham no próprio município de residência e todos aqueles que, apesar de residirem em outra cidade, declaram o município estudado como o local de trabalho -, e não a população ocupada RESIDENTE no município.

Atente-se, ainda, para a diferença entre o indicador ampliado e o estrito. O primeiro inclui, em seu numerador, os imigrantes; no segundo, o numerador se restringe aos pendulares.

Em relação aos imigrantes, as autoras consideraram apenas os mais recentes, captados pelo quesito de data-fixa (imigrantes do período 2005-2010) - admitindo que os mais antigos já se encontram plenamente inseridos na sociedade receptora. Além disso, não consideraram o imigrante natural de retorno como mão de obra exógena, pressupondo-se a migração como um investimento em capital humano para melhor inserção e posicionamento no mercado de trabalho. Em relação aos movimentos pendulares, as autoras trabalharam com seu conceito mais abrangente, tendo em vista as contratações por turnos.

Antes de apresentarem os resultados dos níveis de dependência para os municípios selecionados, Souza e Terra (2015, p. 139) analisaram a relação entre as PEAs ocupada NO e RESIDENTE no município. Como se pode notar na Tabela 10, estima-se um total de 532.851 indivíduos que trabalham em algum dos municípios selecionados, quando sua PEA ocupada residente foi estimada em 497.584 .

Observa-se que, ainda que toda a população ocupada residente em Búzios e em Macaé fosse absorvida pelos respectivos mercados de trabalho, ainda assim haveria postos não preenchidos nesses municípios. Em Armação dos Búzios e Macaé, a população ocupada é cerca de 48\% maior que a ocupada residente. Nos demais municípios, o mercado de trabalho não absorve toda a população ocupada residente, seja por escassez de postos de trabalho, seja pela baixa qualificação profissional da PEA. Nesses casos, a realização da pendularidade surge como importante alternativa para a inserção e a permanência dos indivíduos no mercado de trabalho. É relevante considerar que, além de ser facilitada pelo desenvolvimento dos setores de transporte e comunicação, a pendularidade é, muitas vezes, estrategicamente estimulada pelas diferenças salariais. 
Tabela 10. Municípios selecionados: relação entre a PEA ocupada no município e a PEA ocupada residente no município, por município selecionado (2010)

\begin{tabular}{|l|r|r|r|}
\hline Município Selecionado & $\begin{array}{r}\text { PEA ocupada que } \\
\text { trabalha NO município } \\
(1)\end{array}$ & $\begin{array}{c}\text { PEA ocupada } \\
\text { RESIDENTE no } \\
\text { município (2) }\end{array}$ & $\begin{array}{r}\text { Relação entre as PEA's } \\
(1) /(2)\end{array}$ \\
\hline Armação dos Búzios & 20.164 & 13.596 & 48,31 \\
Arraial do Cabo & 11.224 & 12.573 & $-10,73$ \\
Cabo Frio & 83.256 & 84.792 & $-1,81$ \\
Carapebus & 3.885 & 6.081 & $-36,11$ \\
Campos dos Goytacazes & 183.610 & 186.957 & $-1,79$ \\
Casimiro de Abreu & 14.479 & 17.236 & -16 \\
Macaé & 152.153 & 102.811 & 47,99 \\
Quissamã & 7.868 & 8.621 & $-8,74$ \\
Rio das Ostras & 41.907 & 50.493 & -17 \\
São João da Barra & 14.308 & 14.424 & $-0,8$ \\
Total & 532.851 & 497.584 & 7,09 \\
\hline
\end{tabular}

Fonte: IBGE - Censo Demográfico de 2010.

$\mathrm{Na}$ Tabela 11, encontram-se os resultados das estimativas dos indicadores de dependência de mão de obra exógena. Esse indicador varia entre zero, para mercados de trabalho autossuficientes, e $100 \%$, para os casos de completa dependência. Tais valores são meras referências para a análise dos resultados e, de modo geral, quanto maiores se apresentarem, maior será a dependência do mercado de trabalho em relação à mão de obra exógena.

Tabela 11. Municípios selecionados: nível de dependência de mão de obra exógena (2010)

\begin{tabular}{|c|c|c|c|c|c|c|c|c|c|}
\hline \multirow{3}{*}{$\begin{array}{l}\text { Municipios } \\
\text { Selecionados }\end{array}$} & \multicolumn{6}{|c|}{ Componentes da Mão de Obra exógena } & \multirow{3}{*}{$\begin{array}{c}\text { Mão de obra } \\
\text { ocupada NO } \\
\text { municipio }\end{array}$} & \multirow{3}{*}{$\begin{array}{c}\text { Nível de } \\
\text { Dependência } \\
\text { Ampliado }\end{array}$} & \multirow{3}{*}{$\begin{array}{l}\text { Nível de } \\
\text { Dependência } \\
\text { Estrito }\end{array}$} \\
\hline & \multicolumn{2}{|c|}{ Imigrantes data fixa } & \multicolumn{2}{|c|}{$\begin{array}{l}\text { Pendular intraestadual } \\
\text { total }\end{array}$} & \multicolumn{2}{|c|}{ Pendular interestadual } & & & \\
\hline & Absoluto & $\%$ & Absoluto & $\%$ & Absoluto & $\%$ & & & \\
\hline Armação dos Búzios & 4.041 & 20,0 & 6.997 & 34,7 & 128 & 0,6 & 20.164 & 55,4 & 35,3 \\
\hline Arraial do Cabo & 2.923 & 26,0 & 973 & 8,7 & 2 & 0,0 & 11.224 & 34,7 & 8,7 \\
\hline Cabo Frio & 20.212 & 24,3 & 13.362 & 16,0 & 548 & 0,7 & 83.256 & 41,0 & 16,7 \\
\hline Carapebus & 1.549 & 39,9 & 275 & 7,1 & 6 & 0,2 & 3.885 & 47,1 & 7,2 \\
\hline Campos dos Goytacazes & 45.961 & 25,0 & 7.618 & 4,1 & 1.994 & 1,1 & 183.610 & 30,3 & 5,2 \\
\hline Casimiro de Abreu & 3.340 & 23,1 & 2.193 & 15,1 & 20 & 0,1 & 14.479 & 38,4 & 15,3 \\
\hline Macaé & 38.823 & 25,5 & 42.809 & 28,1 & 9.190 & 6,0 & 152.153 & 59,7 & 34,2 \\
\hline Quissamã & 2.195 & 27,9 & 645 & 8,2 & 25 & 0,3 & 7.868 & 36,4 & 8,5 \\
\hline Rio das Ostras & 12.949 & 30,9 & 6.066 & 14,5 & 322 & 0,8 & 41.907 & 46,1 & 15,2 \\
\hline São João da Barra & 4.482 & 31,3 & 1.492 & 10,4 & 92 & 0,6 & 14.308 & 42,4 & 11,1 \\
\hline Total & 136.475 & 25,6 & 82.430 & 15,5 & 12.324 & 2,3 & 532.851 & 43,4 & 17,8 \\
\hline
\end{tabular}

Fonte: IBGE - Censo Demográfico de 2010.

Como se pode notar na Tabela 11, o nível de dependência ampliado é relativamente alto em todos os municípios. Apenas em Quissamã, Campos dos Goytacazes, Arraial do Cabo e Casimiro de 


\section{A importância da mobilidade populacional para a acumulação capitalista}

Abreu, a dependência ampliada é inferior a 40\%, ou seja, menos de $40 \%$ da mão de obra ocupada no município é exógena. Armação dos Búzios e Macaé apresentaram índices elevadíssimos: 55,4\% e $59,7 \%$, respectivamente.

Em relação ao indicador mais estrito, que considera no numerador apenas a mão de obra pendular, Búzios e Macaé permanecem com os índices mais elevados: 35,3\% e 34,8\%, respectivamente.

Da forma como estão apresentados os resultados, é possível analisar os componentes da pendularidade. Essas informações podem revelar-se muito úteis em contextos nos quais seja necessário adotar medidas para atrair trabalhadores e suprir a carência por mão de obra em determinado mercado de trabalho. Entre os trabalhadores exógenos em Macaé, 57,3\% são pendulares (intra e interestaduais); em Búzios, esse percentual é de 63\%. Em Campos dos Goytacazes, 82,7\% dos trabalhadores exógenos são imigrantes (não naturais e de data fixa).

\section{Considerações finais}

David Harvey (2005) utiliza a teoria marxista para compreender a geografia da acumulação capitalista, considerando que "o capitalismo cria espaços novos para a acumulação" (p. 65) e, para essa criação, necessita "superar as barreiras espaciais e anular o espaço pelo tempo" (idem, ibidem). Nesse sentido, aponta a necessidade de conquistar e levar a indústria para novos espaços, como estratégia para a continuidade do processo de acumulação capitalista.

No caso da indústria do petróleo, essa localização é determinada pela própria localização das jazidas. Isso significa dizer que, se, por um lado, sua instalação gera o desenvolvimento de um setor industrial e de serviços no entorno, por outro lado os demais elementos necessários para a (re)produção capitalista (como mão de obra, transporte e comunicação, entre outros), se estiverem ausentes, devem vir a seu encontro para criar as condições necessárias ao processo de acumulação.

A partir dessa premissa, consideramos que, no contexto do Norte Fluminense, antes produtor de cana-de-açúcar e com uma mão de obra pouco qualificada para as exigências da indústria do petróleo, intensiva em capital, a mobilidade populacional era fator determinante para o processo de acumulação capitalista. Por esse motivo, neste artigo foram pesquisadas as duas formas de mobilidade populacional: migrações internas e pendularidade.

Em relação às migrações, a mais importante sob a ótica da acumulação capitalista nos aglomerados urbanos estudados é a intraestadual, muito embora as migrações interestaduais não devam ser desprezadas. Os municípios que mais atraem imigrantes são: Macaé, Rio das Ostras e Cabo Frio. Em termos relativos, os ritmos de crescimento de todos os municípios na extensão urbana estudada, à exceção de Campos dos Goytacazes, são significativamente influenciados pelas migrações internas.

A pendularidade apresenta-se extremamente elevada, alcançando, inclusive, trabalhadores de outros estados brasileiros, devido à singularidade dos contratos de trabalhadores por turno, do segmento upstream. Mas, assim como ocorre no contexto das migrações internas, os movimentos intraestaduais são os mais significativos. 
Por meio do indicador do nível de dependência, verifica-se elevada dependência por mão de obra exógena nesses municípios, sendo Macaé, onde se situa a base de operações da indústria petrolífera, o que apresenta o maior índice.

Os resultados indicam que, de fato, é por meio das duas formas de mobilidade populacional que esse setor supre sua carência por mão de obra qualificada, indicando que os naturais dos municípios selecionados vêm despendendo esforços no sentido de melhorar sua qualificação profissional e sua posição de inserção e permanência nesses mercados de trabalho. Nesse contexto, tais movimentos são imprescindíveis para a acumulação capitalista e sua ausência implica um ponto de estrangulamento para a atividade da indústria de petróleo, comprometendo o processo de acumulação capitalista na Bacia de Campos.

\section{Referências}

ANP. Anuário Estatístico Brasileiro do Petróleo, Gás Natural e Biocombustiveis. S.1. 2015.

BRITO, Fausto. "Brasil, final do século: a transição para um novo padrão migratório". In CARLEIAL, Adelita (org.). Transições migratórias. Fortaleza: Iplance, 2002.

COSTA, P. "A evolução da indústria petrolífera, uma caracterização geral”. MONIÈ, F. e BINSZTOK, J (orgs.). Geografia e geopolítica do petróleo. Rio de Janeiro: Mauad X, 2012.

EGLER, C. A. G. e MATTOS, M. M. C. L. "Multinacionais no setor petrolífero, geoeconomia e integração regional na América do Sul”. In MONIĖ, F. e BINSZTOK, J. Geografia e geopolítica do petróleo. Rio de Janeiro: Mauad X, 2012.

FARIAS, P. "Nacionalismo e participação popular na campanha 'O petróleo é nosso'”. In PIQUET, R. Petróleo, royalties e regiāo. Rio de Janeiro: Garamond, 2003.

HARVEY, D. "A geografia da acumulação capitalista: uma reconstrução da teoria marxista”. A produção capitalista do espaço. São Paulo: Annablume, 2005.

IBGE. Indicadores sociodemográficos e de saúde no Brasil: estudos e pesquisas. Informação demográfica e socioeconômica. Rio de Janeiro, n. 25, 2009.

- Censo Demográfico de 2010.

- Censo Demográfico de 1991.

- Censo Demográfico de 2000.

OJIMA, R. et al. "A mobilidade pendular na definição das cidades-dormitório: caracterização sociodemográfica e novas territorialidades no contexto da urbanização brasileira”. Cadernos Anpurl UFRJ, v. 21, 2007, pp. 111-32.

PIQUET, R. "Petróleo e desenvolvimento regional no Brasil”. In MONIĖ, F. e BINSZTOK, J. Geografia e geopolítica do petróleo. Rio de Janeiro: Mauad X, 2012.

— e TERRA, D. C. T. "A roda da fortuna: a indústria do petróleo e seus efeitos multiplicadores no Brasil”. In PIQUET, R. (org.). Mar de riqueza, terra de constrastes: o petróleo no Brasil. Rio de Janeiro: Mauad X/Faperj, 2011. 
SOUZA, Joseane e TERRA, Denise C. T. "Indústria petrolífera, mercado de trabalho e nível de dependência da mão de obra exógena nos municípios produtores de petróleo da Bacia de Campos, RJ”, Revista Brasileira de Estudos Urbanos e Regionais, Anpur, v. 17, 2015, p. 123.

_ et al. "O migrante na reestruturação do mercado de trabalho na zona da produção principal da Bacia de Campos”. XVIII Encontro Nacional de Estudos Populacionais, Águas de Lindoia, 2012. _ et al. "A mobilidade pendular entre os municípios da Ompetro-RJ (2000-2010)". Anais... Recife, Encontro Nacional da Anpur, 15, 2013.

— et al. "Mobilidade populacional e as novas espacialidades urbanas: municípios da Ompetro". Eure, Rio de Janeiro (2000-2010), v. 41, 2015, pp. 53-80.

TERRA, Denise C. T et al. "Federalismo no Brasil e o debate sobre o rateio das receitas de petróleo". Revista de Ciências Sociais, Fortaleza, v. 45, n. 2, jul.-dez. 2014, pp. 185-209. 